\title{
The Recollection of Place in Li Daoyuan's Shuijing zhu
}

\section{Introduction: Li Daoyuan and the Shuijing zhu}

The aim of this chapter is to examine how an Early Medieval Chinese geographer perceived, imagined, and represented space. For this purpose, I will consider the geography of the Middle Yangzi basin through the places of memory as presented in the Shuijing $z h u$ 水經注 (Annotated Itineraries of Waterways). It was written by Li Daoyuan 䣓道元 (d. 527), a Chinese literatus who lived under the Northern Wei (386-534), a dynasty founded by a Tabgatch tribe. ${ }^{1}$

Li Daoyuan's work sketches an unprecedented synthesis between an empire-wide space and the human environment that shaped it, through manmade traces. Such traces can belong to the material realm (city walls, remnants of early civil engineering, monasteries, tombs), the immaterial world (literature, stories, myths), or blur the boundaries between the two (through inscribed writings for instance). As the author of a work that is both technical and literary, Li Daoyuan acted as a direct witness when he traveled to observe and record, and as an indirect witness when he used other narratives and documents.

1 The life of Li Daoyuan is essentially known through two official biographies taken from Wei Shou's 魏收 (506-572) Wei shu 魏書 (Book of Wei) and Li Yanshou’s 李延壽 (618-676) Bei shi 北 史 (History of the Northern Dynasties). He is classified in the Wei shu as a harsh official, and he is placed within the biography of his ancestor in the Bei shi (which bears a significantly higher number of information). Originally from Henan, Li Daoyuan was born between 465 and 472 into an official family. His father's professional assignments allowed him to travel across North China from an early age. After he entered the civil service, Li Daoyuan encountered as many promotions as demotions. His severity as well as his skills as an educator are highlighted in both biographies. In 527, he was murdered by the henchmen of defector Xiao Baoyin 蕭寶寅. He wrote his Commentary between 515 and 523. See Wei shu 魏書, Wei Shou 魏收 (Beijing: Zhonghua shuju, 1974), 89. 1925-1926, Bei shi 北史, Li Yanshou 李延壽 (Beijing: Zhonghua shuju, 1997), 27.994-996, and Jörg Henning Hüsemann, Das Altertum vergegenwärtigen: Eine Studie zum Shuijing zhu des Li Daoyuan (Leipzig: Leipziger Universitätsverlag, 2017), 27-47.

Note: For their comments on earlier versions of this text, I would like to thank Garret Olberding, Dagmar Schäfer, former colleagues from the Max-Planck-Institut für Wissenschaftsgeschichte, and two anonymous reviewers.

Ә Open Access. (C 2022 Alexis Lycas, published by De Gruyter. (c) BY-NC-ND This work is licensed under the Creative Commons Attribution-NonCommercial-NoDerivatives 4.0 International License. 
As a rule, the narrative of the Shuijing $z h u$ follows the itinerary of a river course, for it is the river that presides over the hierarchy of the information that is given. As the spatial progression unfolds, the text stops at each important place, goes back in time, sometimes without reference to a logical or chronological sequence of events. Li Daoyuan presents the Shuijing zhu as the potamological commentary of a short anonymous text-the Shuijing 水經, or Itineraries of Waterways. Although the structure of the Shuijing $z h u$ formally follows that of the Shuijing in terms of trajectory and spatial progression, the commentary turns out to be a sum of geographical and historical knowledge that leads to an episteme of space. It is both a synthesis of geographical knowledge approached through a river study and a compendium of the cultural memory of the Empire. ${ }^{2}$

Here, I will not so much focus on motion in space as I will examine movement in time. Li Daoyuan's relation to the past occurs through the constant evocation of places and environments of memory. He did not visit in person all the places he described in the Shuijing zhu: due to the partition of the Empire, he never had the opportunity to cross the Yangzi river and see the southern rivers and sites with his own eyes. When Li Daoyuan lacks the empirical knowledge to comment, or when he wants to complement written sources, he uses myths, legends, testimonies, as well as certain aspects of local lore, to portray as vividly as possible a place he is not familiar with. That being said, he could also decide not to describe a place in case of insufficient material or when in doubt about the reliability of a source. Whether textual or empirical, his investigation is extremely well documented, and provides an inventory of the known world in the beginning of the $6^{\text {th }}$ century. This chapter therefore focuses on the recollection of the past within a specific region, that of the Middle Yangzi area.

2 The Shuijing $z h u$ has been the subject of numerous exegetical studies in China over the last three centuries: see the early 20th century Shuijing zhu tu 水經注圖, by Yang Shoujing 楊守敬 (Beijing: Zhonghua shuju, 2009), and Chen Qiaoyi’s 陳橋驛, four volume Shuijing zhu yanjiu 水 經注研究 (1985-2003). Outside China, sinologists have shown a growing interest in this oftenneglected work: besides Édouard Chavannes' “Les Pays d'occident d'après le Wei Lio,” T'oung Pao 6 (1905): 519-71) and Rolf Stein's "Le Lin-yi, sa localisation, sa contribution à la formation du Champa et ses liens avec la Chine," Han-hiue, Bulletin du centre d'études sinologiques de Pékin 2 (1947): 1-335, more recent studies include contributions by Mori Shikazō 森鹿三 (Tōyōgaku kenkyū: Rekishi chirihen 東洋學研究: 歷史地理篇 (Kyoto: Dōhō, 1970)), Michael Nylan ("Wandering in the Ruins: the Shuijing zhu Reconsidered," in Alan K. Chan and Yuet-Keung C. Lo, eds., Interpretation and Literature in Early Medieval China (Albany: SUNY Press, 2010), 63-101), Jörg Henning Hüsemann (Das Altertum vergegenwärtigen), Alexis Lycas ("Le décentrement du regard géographique dans le Shuijing zhu de Li Daoyuan († 527)," Bulletin de l’École française d'Extrême-Orient 104 (2018): 241-66), and David Jonathan Felt (Structures of the Earth: Metageographies of Early Medieval China (Cambridge, Harvard University Asia Center, 2021)). 


\section{Measuring the past}

The usage of the past, including historical precedents for political legitimation, is a prominent feature of Chinese history and historiography. During Late Antiquity, exegesis became the privileged means for spreading one's own ideas. In that respect, the historical and exegetical significance of the Shuijing zhu is selfevident: even though the initial intention of the author was one of geography, Li Daoyuan gradually moves towards the search for historical traces. ${ }^{3}$

The places of the past are represented in geographical writings so that they can transmit its material, moral and symbolic characteristics to the future. ${ }^{4} \mathrm{Li}$ Daoyuan wishes to be exemplary and to pass on the lessons of the past by linking his own text to older works. To do so, he shapes the memory of the past and he legitimizes certain eras. As we shall see, this is expressed in the way the author names a state, a sovereign, a scholar, a general, and also through his use of historical precedents and edifying narratives, inscribed writings and dynastic names. ${ }^{5}$ Li Daoyuan carries out a two-fold topographical study: in addition to recording all the sites of memory that recount the past, he collects and organizes various media of memory through transmitted literature.

Compiled before the $1^{\text {st }}$ century BCE, the Shanhai jing 山海經 (Itineraries of Mountains and Seas) is generally considered the first attempt to mention places of worship as places of memory. However, the Early Medieval territorial fragmentation became a prominent subject of lament for many literati who regretted the end of imperial unity and had to migrate beyond the Yangzi. This type

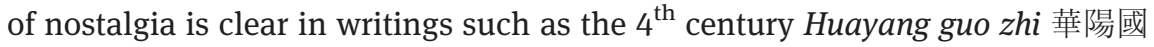
志 (Monograph of the regions south of Mt. Hua) for the area of present-day Sichuan, the $6^{\text {th }}$ century Luoyang Qielan ji 洛陽伽藍記 (Record of the Monasteries of Luoyang) for the capital Luoyang, and of course the Shuijing zhu. Remembrance

\footnotetext{
3 Hou Renzhi 侯仁之, Zhongguo gudai dili mingzhu xuandu 中國古代地理名著選讀 (Hong Kong: Zhonghua shuju, 1963), 96-97.

4 The historian Sima Qian 司馬遷 (145-86 BCE) expressed at the end of the famous letter he sent to his friend Ren An 任安 that “consequently, [they] narrated the past while thinking of future generations” (故述往事, 思來者). See Han shu 漢書, Ban Gu 班固 (Beijing: Zhonghua shuju, 1962), 62.2735, and translation in Stephen Durrant, Wai-yee Li, Michael Nylan, Hans van Ess, The Letter to Ren An and Sima Qian's legacy (Seattle: University of Washington Press, 2016), 28.

5 See Mark Edward Lewis, The Early Chinese Empires: Qin and Han (Cambridge: Belknap Press, 2010), 52, 65, and Martin Kern, “Announcements from the Mountains: The Stele Inscriptions of the Qin First Emperor," in Fritz-Heiner Mutschler and Achim Mittag, eds., Conceiving the Empire. China and Rome Compared (New York: Oxford University Press, 2008), 219-20.
} 
bridges the (sometimes idealized) past and the (often uncertain) present. ${ }^{6}$ The chronological structure of the Shuijing zhu is subordinated to the topographical landscape. As such, it reconstructs entire facets of Early Medieval local history. Moreover, it foreshadows many later works such as "local gazetteers" (difangzhi 地方志), with their rich repository of historical, social and cultural data.

The Northern and Southern dynasties (420-589) as well as the Sui (581-618) and the Tang (618-907) sought their model from the unified Han empire with its state rituals: sacrifices, worship of imperial ancestors, court ceremonies, and imperial rhetoric. Medieval emperors gained legitimacy by being associated with the emperors of the glorious Han and with the wise monarchs of ancient times. ${ }^{7}$ Although it can be traced to earlier periods, this "experience of the past" emerges in the literary and especially in the poetic production of the period, which tends to recreate bygone events. ${ }^{8}$

The remembrance of sites operates on a symbolic level within literary and historical practices. Homer's catalogue of ships and catalogue of the Trojans (as well as his account of Troy as a whole) are written manifestations of an oral memory. ${ }^{9}$ Similarly, the Roman "art [of memory] seeks to memorize through a technique of impressing 'places' [loci] and 'images' [imagines] on memory." the present case, we will encounter artefacts that are as much inscribed memories of the past as they are devices that transmit this very past. ${ }^{11}$ However, I am more interested in examining how Li Daoyuan's recollection of the past can be understood as a source of empirical information. ${ }^{12}$ Li Daoyuan frames his narrative through a thematic series (the rivers of the ecumene), within which other series are revealed: series of mountains, stelae, festivals, legends, etc. He uses or creates a framework - temporal, spatial, and ultimately literary - to record and transmit select past events. Such events are part of an individual mnemonic

\footnotetext{
6 Arthur Wright, "The Sui Dynasty (581-617)," in Denis Twitchett, ed., The Cambridge History of China Volume III. Sui and T'ang China. Part I (Cambridge: Cambridge University Press, 1979), 49, and Charles Holcombe, “Southern Integration: The Sui-Tang (581-907) Reach South,” The Historian 66.4 (2004): 760.

7 Howard Wechsler, Offerings of jade and silk: ritual and symbol in the legitimation of the T'ang Dynasty (New Haven: Yale University Press, 1985), 135-141.

8 Stephen Owen, Remembrances: The Experience of the Past in Classical China (Cambridge: Harvard University Press, 1986), 8, 12.

9 Homer (trans. A. T. Murray, rev. William F. Wyatt), Iliad, Volume I: Books 1-12 (Cambridge: Harvard University Press, 1924), 99-127.

10 Frances Yates, The Art of Memory (London: Pimlico, 1992 ed.), 11.

11 On material aspects of public memory in Early China, see Kenneth Brashier, Public Memory in Early China (Cambridge: Harvard University Asia Center, 2014).

12 Dagmar Schäfer, personal communication.
} 
operation conducted by the author, insofar as it involves the choice of an object within the aforementioned series.

Technically, the Shuijing zhu transmits the characteristics of a place as a historical site in two sequences. First, Li Daoyuan records and catalogs the materiality of a site, its nature as realia: he historicizes a natural or supernatural event by localizing and spatializing it. ${ }^{13}$ Second, the transmission of the symbolic and literary value of a place enables the author to recreate and/or preserve the environment of memory that shaped it, through the narratives and the signs that bring a site to life. ${ }^{14}$ Thus, places are as much mental and literary (the environment of memory and the text itself) as they are physical (administrative units, natural sites, cultural relics). In any case, they are the basis upon which Li Daoyuan builds his argument.

How then does Li Daoyuan historicize his text? He can either describe an event with great precision (year, month, day), or remain rather vague ("originally”, ben 本, “formerly”, $x i$ 昔). Hence, one may wonder why Li Daoyuan can be more or less specific depending on the case? The case of the Battle of Red Cliffs summarizes relatively well the Shuijing zhu's scope on that matter:

The [Yangzi] River passes by the southern slopes of Mount Bairen (hundred-men) on the left, then it passes by the northern slopes of Mount Chibi (red-cliffs) on the right. This is where Zhou Yu's and Huang Gai's deception of the great army of [emperor] Wu of Wei began.

\section{江水左逕百人山南. 右逕赤壁山北, 昔周瑜與黃蓋詐魏武大軍所起也. ${ }^{15}$}

Li Daoyuan only dedicates one line to this major historical event, which proves that he has little interest for a plain event-oriented history. There are several reasons for this. First, Li Daoyuan usually does not feel the need to repeat an episode known to all. Then, he prefers to focus on anecdotes that concern remarkable individuals, but only when their actions are directly linked to the political or religious efficacy of a place. Li Daoyuan often uses allusion and he does not necessarily explain the most important anecdotes, either because they are known or because quoting them would not bring significant elements to the understanding of the place that he wants to convey.

13 Andrew Chittick, “The Development of Local Writing in Early Medieval China,” Early Medieval China 9 (2003): 54.

14 See Pierre Nora, "Entre mémoire et histoire," in Pierre Nora, ed., Les Lieux de mémoire (Paris: Gallimard, 1997), 37, and Paul Ricœur, La Mémoire, l'histoire, l'oubli (Paris: Seuil, 2000), 302-303, 528.

15 Shuijing zhu shu 水經注疏, Li Daoyuan 麗道元 (Yang Shoujing 楊守敬 and Xiong Huizhen 熊會貞, eds., Nanjing: Jiangsu guji chubanshe, 1999), 35.2889. 
Humans take possession of geographic sites in two ways: physically, as they leave traces when they pass by or create artefacts; in language and in writing, when they name, describe, and compare places. Geographic sites are thus transformed into temporal moments and acts of memory when Li Daoyuan inscribes them on paper. ${ }^{16} \mathrm{Li}$ Daoyuan's journey among the topographical space of the empire is complemented by a historical journey through time. The descriptive and thorough work of a geographer becomes the work of a historian too. By combining his philological concerns with spatial representations of the ecumene, Li Daoyuan conveys an innovative historical reflection on the past, and builds a cultural memory of the Empire. ${ }^{17}$

A typological study of the places (rivers, lakes, mountains, human constructions) that are evoked in the Shuijing zhu reveals a catalog of sites of memory, while human constructions (tombs, stelae, altars, walls) inscribe cultural and moral axioms in the Shuijing zhu. Because of their recurrence, these toponymic and onomastic elements structure Li Daoyuan's discourse on space. Whether natural or anthropized, the site is a support for memory, but also an active agent of the transmission of memory. The memory of natural and anthropized sites will be discussed in the following two parts.

\section{Remembering: mountains, monoliths, islands}

Although Li Daoyuan officially comments a potamological text, he describes a fair list of mountains. Chinese geographical writings undeniably contain a wealth of references regarding mountains and rivers, especially the first. ${ }^{18}$ The oldest dictionaries designate them as a natural link between men and heaven. Like humans, mountains are subjected to hierarchy, from the most important to the most negligible. ${ }^{19}$ At the top, one can find the Five Sacred Peaks (wu yue 五浐) whose designation dates back to the ancient mythological literature. Mount

16 For similar questions in Ancient Greece, see Claude Calame, Poetic and Performative Memory in Ancient Greece: Heroic Reference and Ritual Gestures in Time and Space (Cambridge: Harvard University Press, 2009), 25-26.

17 On such a "dialogue with the past" in the Shuijing zhu, see Hüsemann, Das Altertum vergegenwärtigen, 119-148.

18 Michel Soymié, "Le Lo-feou chan: étude de géographie religieuse,” Bulletin de l’École française d'Extrême-Orient 48 (1956): 1.

19 James Robson, Power of Place: The Religious Landscape of the Southern Sacred Peak [Nanyue 南嶽] in Medieval China (Cambridge: Harvard University Asia Center, 2009), 25-31. 
Heng 衡, or the "Southern sacred peak" (Nanyue 南获) is described in the following way in the Shuijing zhu:

The Xiang river flows to the north and passes by Hengshan county on the east. The mountain is located to the southwest, and has three peaks: Zigai (purple-canopy), ${ }^{20}$ Shiqun (circular-stone-granary) and Furong (lotus), the highest and most majestic of all; when observed from afar, its density conceals the sky. Hence Luo Han wrote: "From a distance, [the mountain peaks are] like heaped clouds. The peaks can only be observed on two occasions: after the rain when the sky clears, and at dawn.” The Dan river flows to its left, while the Li cataract runs to its right. [Mount Heng] is called Mount Goulou in the Itineraries of Mountains; it is the Southern [sacred] peak. On the foothills of the mountain is the temple of Shun, ${ }^{21}$ and to its south the mounded tomb of [the tutelary god of fire] Zhurong. In the days of king Ling of Chu, landslides from the mountain destroyed the mound and the "Chart of the Nine heads from Yingqiu" 22 was discovered. When Yu [the Great] regulated the floods, the blood of a horse was used as a sacrifice to the mountain, and the Jade characters on metal slips were obtained. East from peak Furong is the cavern of an immortal. It is not uncommon to hear the clear sound of the declamations of scholars when they pass by.

湘水又北誙衡山縣東, 山在西南, 有三峰, 一名紫蓋, 一名石困, 一名芙蓉, 芙容峰最爲竦傑, 自遠望之, 蒼蒼隱天. 故羅含云: 望若陣雲. 非清䨗素朝, 不見其峰. 丹水湧其左, 澧泉流其 右. 《山經》謂之岣嶁山, 爲南倹也. 山下有舜廟, 南有祝融冢. 楚靈王之世, 山崩, 毀其墳, 得《營丘九頭圖》. 禹治洪水, 血馬祭山, 得《金簡玉字之書》. 芙蓉峰之東, 有仙人石室, 學者經過, 往往聞諷誦之音矣. ${ }^{23}$

The Southern sacred peak is located in the eponymous county, along the Xiang river. It symbolically marks the southern border of the Chinese ecumene: besides connecting man with heaven, it is a natural demarcation, serving as a watchtower for the security of the Empire. ${ }^{24}$ What's more, the mountain is the place where the memory of the empire can be inscribed, as shown in the records of the First Emperor's inspection tours and in the cultural and religious centers that are built on them. ${ }^{25}$ Mount Heng is remembered through the mention of its

20 The purple canopy is one of the emperor's emblems, and it designates the court or the imperial carriage.

21 According to the Chuxue ji 初學記 quoting Luo Han's Xiangzhong ji 湘中記, Mount Heng possesses a temple dedicated to Shun, just like Mount Jiuyi (Shuijing zhu shu, 38.3138).

22 This is taken from Sheng Hongzhi's 盛弘之 Jingzhou ji 荊州記, without Li Daoyuan mentioning it explicitly.

23 Shuijing zhu shu, 38.3137-3138.

24 See Terry Kleeman, "Mountain Deities in China: The Domestication of the Mountain God and the Subjugation of the Margins," Journal of the American Oriental Society 114 (1994): 228, and Garret Olberding, "Movement and Strategic Mapping in Early Imperial China," Мопиmenta Serica 64.1 (2016): 32-33.

25 See below the anecdote of Sun Quan's takeover, and also Shuijing zhu shu, 35.2914-2916. 
majesty and beauty, its link with Yu the Great, and its caverns in which scholars like to withdraw temporarily.

In premodern China, the mountain had several functions. It could be the home of men who had become immortals. By assigning prodigious power to a natural site such as a mountain, texts like the Shanhai jing or the Shuijing zhu transformed it into a sacred entity. Furthermore, many people retired in mountains for political reasons or eremitic purposes, as mountains could be places for self-reflection or artistic production free from social contingencies. ${ }^{26}$ The mountain was also a difficult place to access, and it could be a refuge for non-Chinese populations, but also for exiles.

In antiquity mountains were both feared and venerated. However, from the Eastern Han onward, and particularly during the Northern and Southern Dynasties period, men gradually overcame their fear and acquainted themselves with their orographic environment. ${ }^{27}$ One way of taming a mountain consisted in connecting it to the memory of travel over it or to confer it attributes that would be taken as referents for anyone who would have to describe or travel over it. ${ }^{28}$ Similar to the description of Mount Heng, the following two passages exemplify the grandeur of a mountain. They also underline its potentially overwhelming power, which is linked to the difficulties that arose for those who wished to access it. The first description introduces the story of the encirclement of the Jin forces by the troops of Qiao Daofu 譙道福, a Shu general. Li Daoyuan insists on the sinuosity of the roads to emphasize the impregnability of the mountain:

To the southwest [the ditch] dominates the Grand [Yangzi] River, the view is stunning. Only Peak Ma (horse) presents a slightly sinuous topographic relief. Since a road is pierced through the mountain, one must go through tortuous sheep's gut paths to finally reach the heights [of the peak].

西南臨大江, 䦥之眩目. 惟馬嶺小差委迤, 猶斬山為路, 羊腸數轉, 然後得上. ${ }^{29}$

26 Alan Berkowitz, Patterns of Disengagement: The Practice and Portrayal of Reclusion in Early Medieval China (Stanford: Stanford University Press, 2000). Many mountains were also places were various social or religious communities would gather, often around the figure of a learned man who would teach among disciples. See Valérie Lavoix, "À l'école des collines: l'enseignement des lettrés reclus sous les Dynasties du Sud," in Catherine Despeux and Christine Nguyen Tri, eds., Éducation et instruction en Chine, vol. III: Aux marges de l'orthodoxie (Leuven: Peeters, 2004), 43-65.

27 Paul Demiéville, “La Montagne dans l'art littéraire chinois,” France-Asie 183 (1965): 17, and Robson, Power of Place, 17-20.

28 Shuijing zhu shu, 38.3132.

29 Shuijing zhu shu, 33.2817. 
As Mount $\mathrm{Wu}$ 巫 rises against one of the Three Gorges, Li Daoyuan's literary description goes:

\begin{abstract}
About ten $l i$ downstream [the Yangzi river] stands the great Mount Wu. Not only does it have no matches in the Three Gorges, but it rivals in height with Mounts Min and E[mei] and it reaches the summits of Mounts Heng and [Jiu]yi. The uninterrupted chain of its peaks pierces the azure clouds, and when they reach the firmament, one can then distinguish those that protrude.

其下十餘里, 有大巫山, 非惟三峽所無, 乃當抗峯峮、峨, 偕嶺衡、疑. 其翼附群山, 並泟青 雲, 更就霄漢, 辨其優劣耳. ${ }^{30}$
\end{abstract}

Over the centuries, mountains performed many functions: artistic (as an aesthetic object, the subject of landscape painting or shanshui poetry); military (as a strategic location for battles, as a site to be civilized); social (as community place, as a site of disengagement or even banishment for scholars). The most important function, or at least the most studied, seems to be the religious aspect, especially when a mountain was a site of divinization and sacrifice to heaven. ${ }^{31}$ Whether illustrious or less known, all the mountains are the seat of one or more deities, and the most important ones can sometimes be worshipped and even become divine sites. ${ }^{32}$ In early medieval times, mountains became the epicenters of new religious traditions (messianic Taoist movements, Chan Buddhism), new literary forms (landscape poetry, travel diaries), and their aura reached a climax under the Tang, when poets regularly glorified them. ${ }^{33}$

The anthropization of sites is revealed in several ways: by the stelae, which recount the deeds of men, or by naming a place as a tribute to an illustrious person. There is also an anthropomorphism of the elements: on the Middle Yangzi, one can find a "remarkable rock, which resembles two men facing each other" (奇石. 如二人像). ${ }^{34}$ In the following passage, an anthropomorphic megalith gives its name to the Ren 人 (human) embankment, and this phenomenon is linked to the fact that human figures detach themselves from it, via an almost supernatural mechanism:

Yuan Shansong wrote that "the two banks are separated by a distance of two li. The waters [of the Yangzi] are high and steep when they reach the Ren (human) embankment.

30 Shuijing zhu shu, 34.2832.

31 See for instance Marianne Bujard, Le Sacrifice au Ciel dans la Chine ancienne. Théorie et pratique sous les Han occidentaux (Paris: EFEO, 2000), 152-156.

32 It is the case with the cult to Heaven on Mount Tai 泰. See Édouard Chavannes, Le T'ai chan: essai de monographie d'un culte chinois (Paris: Ernest Leroux, 1910), 3.

33 Demiéville, "La Montagne dans l'art littéraire chinois," 25.

34 Shuijing zhu shu, 34.2841. 
On the south bank a blue rock sticks out: it is immersed in summer, and it emerges from the waters in winter. It is high and steep too. By going tens of paces towards its center, [one sees that] they all are shaped as human faces, some large, others small. By examining further, one can even detect hair and beard [on some faces]. This is the reason why it is called the Ren embankment."

袁山松曰二灘相去二里. 人灘水至峻峭, 南岸有青石, 夏沒冬出, 其石颌崟, 數十步中, 悉作 人面形, 或大或小. 其分明者, 鬚髮皆具, 因名曰人灘也. ${ }^{35}$

Because of their visibility, the warning they pose to ships and their symbolic value, megaliths are spatial markers too. Other cases displaying examples of inscribed folk etymology abound in the Shuijing $z h u$, especially in modern-day Sichuan: Li Daoyuan describes the Shilong 石龍 (stone-dragon) hamlet, the Yinding 淫頂 (excessive-tip) rock which is emerged in winter and submerged in summer, or the Bing 丙 (fishtail) cave which shelters barb fish. ${ }^{36}$ Dangerous rocks often commemorate and symbolize sites of drownings, such as Gou Yanguang's 荷延光:

The Po (broken) rock emerges on the Yangzi. That is the reason why the embankment was named Shipo (broken-stone). It is here that Gou Yanguang drowned.

\section{江上有破石. 故亦通謂之破石灘. 荷延光沒處也. ${ }^{37}$}

The Shuijing zhu also contains the oldest references to rock art: it records a total of nineteen sites displaying petroglyphs (yanhua 嚴畫). ${ }^{38} \mathrm{Li}$ Daoyuan has either heard of them, or seen them with his own eyes. The petroglyphs represent animal forms, spirits, human/animal chimeras, human and animal footprints, weapons and indecipherable signs. Megaliths, inscribed or not, attracted Li Daoyuan's attention, for he diligently records and describes them. South of the Middle Yangzi, he mentions different cases of megaliths, in the area of Changsha:

In the [Lincheng 臨承] district there is a stonedrum. It is six feet high, and the Xiang river runs through it. The sound of the stonedrum resonates when a battle is announced. Luo Junzhang said that "when [the stonedrum is] struck, its resonances propagate to several tens of $l i$ in the surrounding area, but nowadays it no longer emits sound.” To the east of Guanyang district stands peak Pei (long), below which one can find a stonedrum, the

35 Shuijing zhu shu, 34.2843.

36 Shuijing zhu shu, 33.2805, 2812, 2817.

37 Shuijing zhu shu, 33.2809.

38 Chen Zhaofu 陳兆复, Zhongguo yanhua faxian shi 中國岩畫發現史 (Shanghai: Shanghai renmmin, 2009), 23-32; Endymion Wilkinson, Chinese History: A New Manual (Cambridge: Harvard University Asia Center, 2012), 666. 
shape of which resembles that of a flipped boat. When it is struck, the echo spreads in the distance, along the same pattern as the former one.

縣有石鼓, 高六赤, 湘水所逕, 鼓鳴則土有兵革之事. 羅君章云: 扣之, 聲聞數十里, 此鼓今無 復聲. 觀陽縣東有裴巌, 其下有石鼓, 形如覆船, 扣之清響遠徹, 其類也.

To the north, the Xiang river flows along the Yin (seal) stones which lie south of Hengshan district, on the right bank of the Xiang river. Some of the stones are large and others small. The stones on the banks of the river all bear marks on their upper part, and they are square like a seal. They are not inscribed and are all aligned in rows along the river for about two li. That is why these stones are called Yin (seal).

湘水又北歷印石, 石在衡山縣南, 湘水右側. 盤石或大或小, 臨水, 石悉有跡, 其方如印, 纍然 行列, 無文字, 如此可二里許, 因名爲印石也. ${ }^{39}$

In the first case, both stones are drum-shaped and they resonate to announce future battles. The second occurrence indicates a string of originally marked stones-they were named Yin 印 (“seal”)-although their inscriptions were erased over time. As with the stelae (see below, part 3), these patterned stones mark (one could say shape) the memory of the sites, with their presence altering the topography, and their shapes or inscriptions modifying the stones themselves.

Perhaps because they were seen as immersed mountains, islands are often the epicenter of battles, and are generally considered to be auspicious places. The "five islands" are the symbolic starting point of one of the campaigns of the Liu Song (420-479) emperor Xiaowu 孝武 (r. 453-464):

In the middle of the [Yangzi] River, five islands are connected to each other, which is why this place was named Wuzhou (five-islands). When the [Liu] Song emperor Xiaowu raised his troops in Jiangzhou, he established his headquarters on a set of islets, under the (auspicious) shade of a purple cloud. These are the [five] islands.

江中有五洲相接, 故以五洲為名. 宋孝武帝舉兵江州, 建牙洲上, 有紫雲蔭之, 即是洲也. ${ }^{40}$

The hundred islands scattered along the Middle Yangzi were home to foundational accounts of monarchs trying to seize power (successfully or not), or to the unfolding of a battle. At the beginning of the $5^{\text {th }}$ century, the battle between Liu Yi 劉毅 (d. 412) and Huan Xuan 桓玄 (369-404) took place on the Zhengrong 崢嶸 island. The episode forecasts the victory of Liu Yu 劉裕 (363-422)

39 Shuijing zhu shu, 38.3136-3137.

40 Shuijing zhu shu, 35.2918-2919. 
who would eventually establish the Liu Song dynasty. ${ }^{41}$ The following account presents the uplift of an island as an auspicious sign, and focuses mainly on the place and its power:

Of the dozens of islands scattered over the [Yangzi] River on each side of the county, the Baili island is one of the largest. It grows mulberry trees and other trees with sweet fruits; those growing at the edge of the water are reflected in the River. From the west of the district to Shangming, from the east to Jiangjin, there are no less than ninety-nine islands. A proverb of Chu goes: "As long as the number of islands does not reach a hundred, this place can never provide a sovereign." Huan Xuan intended to interrogate the tripod [for he intended to seize the throne], ${ }^{42}$ so he added an island, thus reaching the number of one hundred. A few weeks after he had usurped the throne, his whole clan was exterminated and he was slaughtered. When the case was over, the island was also destroyed. Now that the current sovereign is to the west, an island was suddenly born naturally. Alluvial sediments quickly caused its uplift. Soon after, [the area between] the [Yangzi] River and the [Han] River witnessed the flight of a dragon.

縣左右有數十洲, 槃布江中, 其百里洲最為大也. 中有桑田甘果, 映江依洲. 自縣西至上明, 東及江津, 其中有九十九洲. 楚諺云洲不百, 故不出王者. 桓玄有問鼎之志, 乃增一洲, 以充 百數. 僭號數旬, 宗滅身屠. 及其傾敗, 洲亦消毀. 今上在西, 忽有一洲自生, 沙流回薄, 成不 淹時, 其後未幾, 龍飛江漢矣. ${ }^{43}$

As the previous example shows, this very set of islands can also be the site of a tragic double death, that of Huan Xuan and his son. ${ }^{44}$ Huan Xuan was a warlord who proclaimed himself emperor of an ephemeral kingdom of Chu 楚, which he established in 403. He was killed the following year, during an offensive led by Liu Yu. Retrospectively considered a usurper because the founder of the Liu Song dynasty defeated him, Huan Xuan made a second mistake by adding an extra island and thus upset the order of things. As the second example shows, the natural uplift of a hundredth island coupled with the flight of a dragon signaled the advent of a sovereign, ${ }^{45}$ in that case Liu Yu. There again, the place influences history, and vice versa. In the following section, I will analyze the different ways of remembering human traces.

41 Shuijing zhu shu, 35.2904.

42 It is a reference to the Nine tripods (jiuding 九鼎) cast by Yu the Great with the metal that was given to him by the Nine provinces he established. It went on to designate an unsuccessful plot to seize power.

43 Shuijing zhu shu, 34.2855.

44 Shuijing zhu shu, 34.2859.

45 As recounted for the first time in the Yijing 易經. See Zhou yi zhengyi 周易正義, Shisan jing zhushu 十三經注疏, Ruan Yuan 阮元, ed. (Beijing: Zhonghua shuju, 1980), 1.10a. 


\section{Commemorating: temples, tombs, stelae}

As early as the $6^{\text {th }}$ century, literati like Li Daoyuan or Yan Zhitui 顏之推 (531-591), the author of the Yan shi jiaxun 顏氏家訓 (Family Instructions of the Yan Clan), would confront epigraphic documents with classical learning. ${ }^{46}$ Temples, tombs and stelae are commemorative sites which record the memory of the dead. They reveal, like the mountains, a set of practices such as ancestral cults, political events, expression of filial piety. The topography of the dead emphasizes the importance that should be given to these sites, as well as to the place that commemorates them. ${ }^{47}$ These sites tell the story of the eras favored by Li Daoyuan in his narrative, namely High Antiquity, Han times and the Three Kingdoms period. The deities or spirits to which a temple is dedicated may be past emperors, eminent individuals, cosmic forces, nature spirits, etc. Although temples were mostly devoted to emperors and/or deities, commoners could also enjoy this privilege as long as their conduct justified it.

An illustration of Li Daoyuan's commemorative method can be found in the next example. In addition to mentioning a temple devoted to $\mathrm{Yu}$ the Great and located on Mount Tu 塗, ${ }^{48}$ it mentions the site of memory of Xiang 象, Shun's 舜 younger brother. As Xiang's life was unworthy of Shun's, Li Daoyuan pretends to wonder why a temple dedicated to Xiang could be an auspicious place:

The Ying river flows southeasterly and passes by the southern side of Youbi's [funeral] mound..$^{49}$ Wang Yin ${ }^{50}$ writes: "Yingyang county was originally the northern part of Quanling [county]. Five li to the east stands Youbi's mound, where it is said that Xiang was enfeoffed. On the foothills of the mountain is the temple of Xiang, whose spirit is said to have had virtues of efficacy, and was capable of arousing clouds and rain [of benefits]." I have heard that the spirit of the saints was the soul, and that the essence of the wise was the spectre. Xiang not having led an enlightened life, once dead, where could his soul have stayed? The Ying river continues its course to the southeast and flows into the Xiang river.

46 See Olivier Venture, “Nouvelles sources écrites pour l'histoire des Qin,” Journal Asiatique 301.2 (2013): 503.

47 Kenneth Brashier, Ancestral Memory in Early China (Cambridge: Harvard University Asia Center, 2011), 160-164.

48 Shuijing zhu shu, 33.2795.

49 It is the name of a fiefdom given to Xiang by Shun.

50 He was an early $4^{\text {th }}$ century defector who joined the South before the dynastic transition. He wrote a Jin shu. See his biography in Jin shu 晉書, Fang Xuanling 房玄齡 (Beijing: Zhonghua shuju, 1974), 82.2141. 
應水又東南流, 逕有鼻墟南. 王隱曰: 應陽縣本泉陵之北部, 東五里有鼻墟, 言象所封也. 山 下有象廟, 言甚有靈, 能興雲雨. 余所聞也, 聖人之神曰靈, 賢人之精氣爲鬼, 象生不慧, 死靈 何寄乎? 應水又東南流而注于湘水. ${ }^{51}$

Upstream from the Yangzi, we find an example of a prodigious temple and the respect it inspires to powerful men and commoners alike:

On the Qutang embankment there is the temple of a [local] god, where prodigies have already occurred. When officials with the rank of regional inspector or two thousand bushels officers ${ }^{52}$ pass here, no one is allowed to play the trumpet or to strike a drum. When merchants go down or up [the Yangzi River], they dread making noise by touching the rocks. That is why they wrap the tip of their pole with a piece of cloth. Although [these prodigies] no longer occur, sacrifices remain in practice.

矍塘灘上有神廟, 尤至靈驗. 刺史二千石徑過, 皆不得鳴角伐鼓. 商旅上下, 恐觸石有聲, 乃 以布裹篙足. 今則不能爾, 猶饗萀不輟. ${ }^{53}$

Many temples were built in remembrance of emperors and sovereigns. Under the Han, a memorial temple for Emperor $\mathrm{Wu}$ 武 was erected at the Tao 桃 pass. ${ }^{54}$ A very interesting conflict between the future Eastern Han emperor Guangwu 光武 (r. 25-57) and Wang Mang 王莽 (45 BCE-23 CE) took place during the early first century:

At the time when Shizu (Guangwu emperor of the Eastern Han) was still of humble condition, ${ }^{55}$ he passed through Jiangyang county. He had a son. A diviner specializing in the observation of emanations had said that an eminent boy would appear in Jiangyang. Wang Mang had him fetched, captured and killed. Shizu was seized with hatred. He had an ancestral temple dedicated to his son built in the district. He blamed the people of the county and requested them to pay fines for several generations.

昔世祖微時, 過江陽縣, 有一子. 望氣者言江陽有貴兒象, 王莽求之, 而獠殺之. 後世祖怨, 為 子立祠於縣, 謫其民罰布數世. ${ }^{56}$

Although Guangwu ended up erecting a temple to expiate Wang Mang's wrongdoings, this anecdote brings together different levels of historical signification, from the very local causes and consequences (a regional quarrel at the margins of the realm, the implicit involvement of the local community and the fiscal

51 Shuijing zhu shu, 38.3131-3132.

52 "Two thousand bushels" is a way to designate the inspectors and governors according to their annual stipend.

53 Shuijing zhu shu, 33.2819-2820.

54 Shuijing zhu shu, 33.2743.

55 That is "before seizing power."

56 Shuijing zhu shu, 33.2786. 
consequences of their actions), to an impact on the imperial level (via the power of divination and the suggested impetus given to Guangwu). The memory of this event is mediated through the construction of the temple.

Sixty li northeast of the village where the great poet Qu Yuan 屈原 (fl. 4th3rd centuries BCE) lived, stands the temple of his sister Nüxu 女須. ${ }^{57}$ Another temple was erected for Wang Zixiang 王子香, a virtuous and benevolent official of the Eastern Han, who died while he was inspector of Jing 荊 province. His kindness manifested itself posthumously through the symbolic appearance of three white tigers who carried his remains. Moreover, an ancestral temple and a commemorative stele were built for him, and he was given the title of "gentleman-prince of the white tigers of Zhijiang” (枝江白虎王君). ${ }^{58}$

Li Daoyuan also presents the erection of the Damu 大姥 (venerableancestress) temple, which is related to the episode of Sun Quan's 孫權 (182-252) seizure of power as recorded in the Wuchang ji 武昌記 (Record of Wuchang); he then quotes Ying Shao's 應劭 $2^{\text {nd }}$ century Han guan 漢官 (Han officials [serving non-Chinese rulers]). The narrative pattern is the following: the event takes place, it has an impact (the coronation) and as a result a temple is built to commemorate the event. Thereafter, Li Daoyuan mentions the following generation (Sun Hao 孫皓 [242-284], the last sovereign of Wu, and Wang Fan 王蕃 [228-266]), before going back to Sun Quan's times: the description of his sacrificial altar evokes the various spatial stages of his coronation and his good government, through graphic descriptions of his own libations and his court:

To the south of the wall is Mount Yuan, which is another name for Mount Fan. The Record of Wuchang says: "the Damu temple (venerable-ancestress) is located south of the Fan mouth. Sun Quan used to hunt on [the foothills of] the mountain. One evening, at dusk, he met an old lady who asked him what he had caught during the day. [Sun Quan] replied: 'I only caught a panther.' The woman said: 'And why do not you set upright the panther's tail? ${ }^{59}$ Then she suddenly disappeared.” Ying Shao wrote in the introduction to the Han Officials [serving non-Chinese rulers]: "After the passage of the panther tail [caravan], the lictors ${ }^{60}$ stop the procession and disperse. When the Imperial guard procession takes the road, the last car of the procession sports a panther's tail. It means that this is where the sovereign is seated." Since [Sun] Quan acceded to the imperial dignity here, he had a temple built on this site. Sun Hao also climbed this mountain: he sent a general to

57 Shuijing zhu shu, 34.2837.

58 Shuijing zhu shu, 34.2857.

59 That is "why don't you take responsibility and declare yourself emperor?" A symbol of the imperial caravan, a panther's tail (or a painting representing it) is attached to one of the cars (usually the last) and it is understood as an imperial banner.

60 Zhijinwu 執金吾 is an alternative form of jinwu (a supernatural bird who can remove evil spells; here, the imperial herald, during the Han). 
kill the official Wang Fan, and convinced [Wang Fan's followers] that his head had been torn off by a tiger. To the north [Mount Yuan] borders the Grand [Yangzi] River on which there is a fishing terrace where [Sun] Quan liked to drink heavily. He said: 'We will not stop drinking until we fall backwards!' It was here that Zhang Zhao ${ }^{61}$ came to offer his honest and benevolent admonitions [to Sun Quan]. To the west of the wall is the Jiao (peripheral) altar where [Sun] Quan offered a sacrifice to Heaven and obtained the position of emperor. Looking around him, he addressed his ministers: 'What Lu Zijing (172-217) ${ }^{62}$ said in the past [happened], we must recognize his clairvoyance regarding the outcome of things in the world.' To the east of the wall is an old enclosure, which is said to have been erected by the Han general Guan Ying (d. 176 BCE).

城南有袁山, 即㚞山也. 武昌記曰㚞口南有大姥廟, 孫權常獵於山下, 依夕, 見一姥, 問權獵 何所得. 曰止得一豹. 母曰何不豎豹尾. 忽然不見. 應助漢官序曰豹尾過後, 執金吾罷屯, 解 圍. 天子㔽簿中, 後屬車施豹尾. 于道路, 豹尾之内為省中. 蓋權事應在此, 故為立廟也. 又孫 皓亦嘗登之, 使將害常侍王蕃, 而以其首虎爭之. 北背大江, 江上有釣臺, 權常極飲其上曰墮 臺醉乃已. 張昭盡言處. 城西有郊壇, 權告天即位於此, 顧謂公卿曰魯子敬嘗言此, 可謂明于 事勢矣. 城東故城, 言漢將灌嬰所築也. ${ }^{63}$

The memory of space is transmitted through references to the toponyms and anthroponyms that are associated to a particular site. Enumerating them enables both the author and the reader to situate themselves and locate these sequences in space, physically and mentally. To attest the past existence of a site, one must associate to the name of the site the name of a person or of an event that occurred there. Here, Li Daoyuan mentions several persons, and he insists on the conditions of Sun Quan's rise to power, while blending supernatural anecdotes together with the "reality" of the imperial cult and the friendly libations. The "presence" of these persons gives an undeniable value to the place by attesting to its importance and inscribing it permanently in the political memory of Sun Quan's seizure of power. A place can become a site of memory only if something has happened at the site. What actually happened is not so important, provided it can bear witness to the site's strength and secularity, and as long as it is the product of human factors, individual or collective.

In the $3^{\text {rd }}$ century, when the founder of the Shu kingdom Liu Bei 劉備 (161-223) died, his great minister and advisor Zhuge Liang 諸葛亮 (181-234) inherited power at the Yong'an 永安 palace. Li Daoyuan employs this event to highlight the power of Nature and especially of the tumultuous waters that destroyed the wall surrounding the palace. He emphasizes the importance of

61 Zhang Zhao 張昭 (156-236) was a scholar, close advisor and honest critic of Sun Quan.

62 It refers to Lu Su's 魯肅 social name. He was a politician, general and diplomat who advised Sun Quan during his conquest to power. He died before Sun Quan was crowned.

63 Shuijing zhu shu, 35.2914-2916. 
remembering Nature's ability to regain ground and the ephemeral nature of these constructions:

The plain between the two measures about twenty li. The long distance that separates mountains and rivers disappears once one enters the canyon. Leaning on the mountain and bordered by the [Yangzi] River, the surrounding walls have a perimeter of a dozen $l i$. The enclosure was destroyed from all sides and invaded by brambles and wild bushes coming from all sides. Many local inhabitants now reclaim land among these ruins.

其閒平地可二十許里, 江山迥闊, 入峽所無. 城周十餘里, 背山面江, 頽塘四毀, 荊棘成林, 左 右民居多墾其中. ${ }^{64}$

Temples and stelae are also erected to commemorate individuals from the past who perished from unnatural or natural death. They are often places where prodigies manifest themselves. ${ }^{65}$ Apart from referring to the main characters of the Three Kingdoms, the temples mentioned in the Shuijing zhu refer to two other periods that are considered to be golden ages: the High Antiquity, with particular reference to $\mathrm{Yu}$ the Great and his descendants, and both Han dynasties.

The remembrance of individuals is concretized by the fact that stelae and tombs commemorate them. Li Daoyuan mentions a total of two hundred and seventy-eight stelae dedicated to remarkable individuals, who are mostly emperors, civil servants and generals. These stelae, however, only date back as far as the Han period. ${ }^{66}$ They play a significant part in the transmission of memory, insofar as cults and stelae are intimately linked. In early China, governing often meant performing sacrifices, and erecting these stelae represented as much a religious testimony as a political memory that aims at inscribing official practices in space. ${ }^{67}$ In doing so, stelae and other visually inscribed artifacts blur and bridge the frontier between the material and immaterial realms.

The memory of Shun seems all the more monumentalized since three temples and a stele were erected to convey it: two temples were built on Mount Jiuyi 九疑, while another temple was located further north on the foothills of Mount Heng, the Southern sacred peak. ${ }^{68}$ The magnitude of Shun's stele and

64 Shuijing zhu shu, 33.2813.

65 Alexis Lycas, "La mort par noyade dans la littérature géographique du haut Moyen Âge chinois,” Études chinoises 36.1 (2017): 51-77.

66 Shi Zhicun 施執存. Shuijing zhu beilu 水經注碑錄 (Tianjin: Tianjin guji chubanshe, 1987); Miranda Brown, The Politics of Mourning in Early China (Albany: SUNY Press, 2008), 16-17, 141.

67 Jean Levi, "The Rite, the norm and the Dao: philosophy of sacrifice and transcendence of power in Ancient China," in John Lagerwey and Marc Kalinowski, eds., Early Chinese Religion. Part One: Shang through Han (1250 BC-220 AD) (Leiden: Brill, 2009), 645-648.

68 Shuijing zhu shu, 38.3138. 
the fact that he is given precedence over his son can be experienced in the topography of the place:

The great Shun is buried at the adret of Mount [Jiuyi], while [his son] Shang Jun is buried at the ubac. To the south of the mountain is Shun's temple, in front of which a stele was erected. Its characters are eroded and incomplete, which makes their identification impossible. When raising one's head from the temple toward the highest peaks, one's gaze can rise to a hundred li. According to the traditions of the elders, no man ever reached the summits of these peaks. To the northeast of Mount [Jiuyi], at the border of Lingdao county, there is another temple dedicated to Shun. To the south of the county stands Shun's stele, which was erected by $\mathrm{Xu}$ Jian, the governor of Lingling.

大舜窔其陽, 商均葬其陰. 山南有舜廟, 前有石碑, 文字缺落, 不可復識. 自廟仰山極高, 直上 可百餘里. 古老相傳, 言未有登其峰者. 山之東北, 泠道縣界, 又有舜廟. 縣南有《舜碑》, 碑 是零陵太守徐儉立. ${ }^{69}$

Li Daoyuan also mentions two more stelae with apparently illegible inscriptions. Since he is unable to decipher them, he prefers not to attribute them to anyone, although it seems that they refer to persons of importance, most probably Shun in the first case, and perhaps the Marquis of Jie 節 in the second case. ${ }^{70}$

\section{Conclusion}

Most of the monuments listed in the Shuijing zhu refer to a glorious past, usually dating back more than a century before Li Daoyuan's times. ${ }^{71}$ Their names are at the heart of the operation of remembrance: they are essential and iterative markers that enable the memory of places to endure. Such a process manifests itself near a fortress erected by Zinang 子囊 (d. 559 BCE), son of king Zhuang 莊 of Chu, with the tomb of Zhao Qi 趙岐 (108-201), who was known for commenting the Mengzi 孟子. This tomb “was built by [Zhao] Qi during his lifetime. Portraits of the host and his guests were drawn to inscribe their friendship and also to show what they ordinarily attached importance to.” (岐平生自 所營也. 冢圖賓主之容, 用存情好, 敘其宿尚矣) ${ }^{72}$

69 Shuijing zhu shu, 38.3123-3125.

70 Shuijing zhu shu, 38.3127.

71 Michael Nylan, "Wandering in the Ruins: the Shuijing zhu Reconsidered,” in Alan K. Chan and Yuet-Keung C. Lo, eds., Interpretation and Literature in Early Medieval China (Albany: SUNY Press, 2010), 64-66. For a list of the Middle Yangzi stelae, see Shi, Shuijing zhu beilu, 381-433.

72 Shuijing zhu shu, 34.2865. 
Monuments are not only mentioned to honor illustrious figures (emperors, mythical sovereigns) at the imperial level, but also to remember generals or local lords at the regional level. Thus, several stelae were erected near the mouth of the Mian 㑂 river, next to a fort built by Lu Huan 陸渙 ( $3^{\text {rd }}$ century governor of Jiangxia). They commemorate the actions of three soldiers-Liu Qi 劉琦 (d. 209) at the very end of the Han, Hu Fen 胡奮 (d. 288) and Wang Yi 王庴 (276-322) during the Three Kingdoms and Jin periods-who distinguished themselves in combat between the $3^{\text {rd }}$ and $4^{\text {th }}$ centuries:

\begin{abstract}
[Situated on the mountain, Lu Huan's fort] was established in the sixth year of the reign of the Han emperor Gao (201 BCE), and it was moved here under the Wu. The stele of "Hu Fen, inspector of Jing province and general of the expedition to the South of Jin" was erected in the middle of the fort, and so was the stele engraved by Wang Shijiang, the general for pacifying the South, which recounts the events of the punitive expedition against Du Zeng. One can also find there the tomb of Liu Qi and his ancestral temple.
\end{abstract}

漢高帝六年置, 吳乃徙此. 城中有晉征南將軍荊州刺史胡奮碑. 又有平南將軍王世將刻石記 征杜曾事. 有劉琦墓及廟也. ${ }^{73}$

Liu Qi was the eldest son of Liu Biao 劉表 (142-208), the powerful governor of Jing province at the end of the Han. After having assisted Liu Bei in the Battle of Changban and participated in the Battle of Red Cliffs, he was appointed inspector of Jing province; he died shortly after his appointment. ${ }^{74} \mathrm{Hu}$ Fen was a famous Jin general known for fighting the Xiongnu and launching the final expedition against the Wu kingdom. Wang Yi 王庴 (276-322) was an official, a painter, a calligrapher, a musician, and the first cousin of the powerful and rebelious stateman Wang Dun 王敦 (266-324); he was appointed inspector of Jing province during the Eastern Jin. ${ }^{75}$ As for Du Zeng 杜曾 (d. 319), he was a Western Jin felon who suffered two successive defeats in 317 and 319; the latter was fatal: he was betrayed and delivered by his officers to Zhou Fang 周訪 (260-320), an important general and inspector of Eastern Jin, who helped the dynasty to reaffirm control of the Middle Yangzi area. ${ }^{76}$ Through an iterative process that displays the memory of the illustrious military men who fought in this area, these stelae both recollect and celebrate past worthies in linkeage with the imperial topography.

Similarly and in addition to stelae, altars (tan 壇), such as the Jie 界 altar which marks the western boundary of the Badong 巴東 region, and cairns (lei 壘),

73 Shuijing zhu shu, 35.2895-2896.

74 Hou Han shu 後漢書, Fan Ye 范瞱 (Beijing: Zhonghua shuju, 1965), 74B.2423-2424.

75 Jin shu, 76.2002-2012.

76 Jin shu, 58.1581. 
such as the one erected as a tribute to Zhuge Liang's strategic talents, are commemorative monuments that contribute to the remembrance of a place. ${ }^{77}$

In conferring memory to natural as well as anthropized sites, Li Daoyuan recollects the past. In addition to recording numerous books (that were lost between his time and the Song dynasty), he also wishes to pass on remnants of material culture. This is not surprising, as inscribed artifacts are indeed a durable support used to engrave important events or texts. ${ }^{78}$ The values attributed to those inscriptions are that of exemplarity and authority, and they are further commemorated through their dating. Overall, if we focus on descriptions of topographical objects (mountains, monoliths, islands) and man-made monuments (temples, tombs, stelae), Li Daoyuan's strategies in representing sites of memory come to the fore. The spatial configurations of the material past together with the retrospective gaze of the author reveal a deeply original way of representing places in Early Medieval China.

\section{References}

\section{Primary sources}

Bei shi 北史, Li Yanshou 李延壽 (Beijing: Zhonghua shuju, 1997).

Han shu 漢書, Ban Gu 班固 (Beijing: Zhonghua shuju, 1962).

Hou Han shu 後漢書, Fan Ye 范瞱 (Beijing: Zhonghua shuju, 1965).

Jin shu 晉 書, Fang Xuanling 房玄齡 (Beijing: Zhonghua shuju, 1974).

Shuijing zhu shu 水經注疏, Li Daoyuan 琚道元 (Yang Shoujing 楊守敬 and Xiong Huizhen

熊會貞, eds. Nanjing: Jiangsu guji chubanshe, 1999).

Shuijing zhu tu 水經注圖, Yang Shoujing 楊守敬 (Beijing: Zhonghua shuju, 2009).

Wei shu 魏書, Wei Shou 魏收 (Beijing: Zhonghua shuju, 1974).

Zhou yi zhengyi 周易正義, Shisan jing zhushu 十三經注疏, Ruan Yuan 阮元, ed. (Beijing:

Zhonghua shuju, 1980).

77 Shuijing zhu shu, 33.2802, 2813.

78 See Marianne Bujard's ongoing research project on the temples and stelae of Beijing: Beijing neicheng simiao beikezhi 北京內城寺廟碑刻志 (Beijing: Guojia tushuguan chubanshe, 2011-2020). 


\section{Secondary sources}

Berkowitz, Alan J. Patterns of Disengagement: The Practice and Portrayal of Reclusion in Early Medieval China (Stanford: Stanford University Press, 2000).

Brashier, Kenneth. Ancestral Memory in Early China (Cambridge: Harvard University Asia Center, 2011).

Brashier, Kenneth. Public Memory in Early China (Cambridge: Harvard University Asia Center, 2014).

Brown, Miranda. The Politics of Mourning in Early China (Albany: SUNY Press, 2008).

Bujard, Marianne, ed. et al. Beijing neicheng simiao beikezhi 北京內城寺廟碑刻志 (Beijing: Guojia tushuguan chubanshe, 2011-2020).

Bujard, Marianne. Le Sacrifice au Ciel dans la Chine ancienne. Théorie et pratique sous les Han occidentaux (Paris: EFEO, 2000).

Calame, Claude. Poetic and Performative Memory in Ancient Greece: Heroic Reference and Ritual Gestures in Time and Space (Cambridge: Harvard University Press, 2009).

Chavannes, Édouard. Le T'ai chan: essai de monographie d'un culte chinois (Paris: Ernest Leroux, 1910).

Chavannes, Édouard, “Les Pays d'occident d’après le Wei Lio,” T’oung Pao 6 (1905): 519-71.

Chen Qiaoyi 陳橋驛. Shuijing zhu yanjiu 水經注研究 (Tianjin: Tianjin guji chubanshe, 1985-2003).

Chen Zhaofu 陳兆复. Zhongguo yanhua faxian shi 中國岩畫發現史 (Shanghai: Shanghai renmmin, 2009).

Chittick, Andrew, "The Development of Local Writing in Early Medieval China," Early Medieval China 9 (2003): 35-70.

Demiéville, Paul, “La Montagne dans l'art littéraire chinois,” France-Asie 183 (1965): 7-32.

Durrant, Stephen, Li, Wai-yee, Nylan, Michael, van Ess, Hans. The Letter to Ren An and Sima Qian's legacy (Seattle: University of Washington Press, 2016).

Felt, D. Jonathan. Structures of the Earth: Metageographies of Early Medieval China (Cambridge, Harvard University Asia Center, 2021).

Holcombe, Charles, "Southern Integration: The Sui-Tang (581-907) Reach South," The Historian 66.4 (2004): 749-71.

Homer (A. T. Murray trans., William F. Wyatt rev.). Iliad, Volume I: Books 1-12 (Cambridge: Harvard University Press, 1924).

Hou Renzhi 侯仁之, Zhongguo gudai dili mingzhu xuandu 中國古代地理名著選讀 (Hong Kong: Zhonghua shuju, 1963).

Hüsemann, Jörg Henning. Das Altertum vergegenwärtigen: Eine Studie zum Shuijing zhu des Li Daoyuan (Leipzig: Leipziger Universitätsverlag, 2017).

Kern, Martin, “Announcements from the Mountains: The Stele Inscriptions of the Qin First Emperor," in Fritz-Heiner Mutschler and Achim Mittag, eds., Conceiving the Empire. China and Rome Compared (New York: Oxford University Press, 2008), 217-40.

Kleeman, Terry, "Mountain Deities in China: The Domestication of the Mountain God and the Subjugation of the Margins," Journal of the American Oriental Society 114 (1994): 226-38.

Lavoix, Valérie, “À l'école des collines: l'enseignement des lettrés reclus sous les Dynasties du Sud," in Catherine Despeux and Christine Nguyen Tri, eds., Éducation et instruction en Chine, vol. III: Aux marges de l'orthodoxie (Leuven: Peeters, 2004), 43-65. 
Levi, Jean, "The Rite, the norm and the Dao: philosophy of sacrifice and transcendence of power in Ancient China," in John Lagerwey and Marc Kalinowski, eds., Early Chinese Religion. Part One: Shang through Han (1250 BC-220 AD) (Leiden: Brill, 2009), 645-92.

Lewis, Mark Edward. The Early Chinese Empires: Qin and Han (Cambridge: Belknap Press, 2010).

Lycas, Alexis, "La mort par noyade dans la littérature géographique du haut Moyen Âge chinois," Études chinoises 36.1 (2017): 51-77.

Lycas, Alexis, "Le décentrement du regard géographique dans le Shuijing zhu de Li Daoyuan († 527)," Bulletin de l'École française d'Extrême-Orient 104 (2018): 241-66.

Mori Shikazō 森鹿三. Tōyōgaku kenkyū: Rekishi chirihen 東洋學研究: 歷史地理篇 (Kyoto: Dōhō, 1970).

Nora, Pierre, "Entre mémoire et histoire," in Pierre Nora, ed., Les Lieux de mémoire (Paris: Gallimard, 1997), 23-48.

Nylan, Michael, "Wandering in the Ruins: the Shuijing zhu Reconsidered," in Alan K. Chan and Yuet-Keung C. Lo, eds., Interpretation and Literature in Early Medieval China (Albany: SUNY Press, 2010), 63-101.

Olberding, Garret, "Movement and Strategic Mapping in Early imperial China," Monumenta Serica 64.1 (2016): 23-46.

Owen, Stephen. Remembrances: The Experience of the Past in Classical China (Cambridge: Harvard University Press, 1986).

Ricœur, Paul. La Mémoire, l'histoire, l'oubli (Paris: Seuil, 2000).

Robson, James. Power of Place: The Religious Landscape of the Southern Sacred Peak [Nanyue 南获] in Medieval China (Cambridge: Harvard University Asia Center, 2009).

Shi Zhicun 施執存. Shuijing zhu beilu 水經注碑錄 (Tianjin: Tianjin guji chubanshe, 1987).

Soymié, Michel, "Le Lo-feou chan: étude de géographie religieuse," Bulletin de l'École française d'Extrême-Orient 48 (1956): 1-139.

Stein, Rolf, "Le Lin-yi, sa localisation, sa contribution à la formation du Champa et ses liens avec la Chine," Han-hiue, Bulletin du centre d'études sinologiques de Pékin 2 (1947): 1-335.

Venture, Olivier, “Nouvelles sources écrites pour l'histoire des Qin," Journal Asiatique 301.2 (2013): 501-514.

Wechsler, Howard. Offerings of jade and silk: ritual and symbol in the legitimation of the T'ang Dynasty (New Haven: Yale University Press, 1985).

Wilkinson, Endymion. Chinese History: A New Manual (Cambridge: Harvard University Asia Center, 2012).

Wright, Arthur, "The Sui Dynasty (581-617)," in Denis Twitchett, ed., The Cambridge History of China Volume III. Sui and T'ang China. Part I (Cambridge: Cambridge University Press, 1979), 48-149.

Yates, Frances. The Art of Memory (London: Pimlico, 1992 ed.). 